\title{
TIDAK SAH PERWALIAN KARENA TIDAK SAH PERNIKAHAN
}

\author{
Ibnu Jazari \\ Fakultas Agama Islam Universitas Islam Malang \\ e-mail: ibnujazari11@gmail.com
}

Diterima: 06-06-2020 | Direvisi: 24 Juni 2020 | Disetujui: 12 September 2020

(C) 2019 Program Studi Ahwal Syakhshiyyah Fakultas Agama Islam Universitas Islam Malang

\begin{abstract}
Abstrak
Ketika ada seorang Wanita yang hilang keperawannya dengan perzinahan bagaimanakah hukum perkawinan berikutnya. ketika ada anak gadis yang masih dibawah umur ingin menikah, namun yang menjadi wali nikah adalah kakeknya, bukan ayah kandungnya, padahal ayah kandungnya masih ada dan kuasa atas perwaliannya. penggunaan metode kualitatif dalam penelitian. Metode ini Bersifat lebih ke arah metode kajian atas gagasan konseptual. Sedangkan data yang dikumpulkan dan yang akan dianalisis bertumpu pada ketersediaan sumber data di perpustakaan (Library Research).Teknik analisis data yang digunakan dalam kajian ini adalah teknik analisis isi (Content Analysis). perwalian menjadi syarat sah dan rukun dari pernikahan sehingga dalam pernikahan wali harus hadir ditempat, atau yang mewakilinya. jelaslah untuk menjadi wali dalam pernikahan tidaklah sembarang orang, namun haruslah memenuhi syarat dan rukunnya. Wali pernikahan selalu dari pihak ayah, hal ini disebabkan oleh adanya nasab (pertalian kekeluargaan yang didasakan pada pernikahan yang sah). Dari penjelasan diatas seorang anak bernasab pada ayahnya, sehingga jika aada anak yang mau menikh maka yang menjadi walinya adalah orang-orang yang jelas sedarah dengan anak tersebut. Tidak adanya wali pernikahan dari pihak ibu atau dari pihak saudara perempuan seperti halnya kakek dari ibu, saudara laki-laki ibu dan seterusnya. Dalam pernikahan hendaklah mengurutkan wali dari yang paling dekat sebagaimana yang dijelaskan diatas. Tidaklah boleh dilangkahi. Semisal memakai wali yang jauh, sementara wali yang dekat masih ada dan tidak ada udzur. Wali yang paling akhir untuk menikahkan seorang wanita mslim ialah wali hakim.
\end{abstract}

\section{A. Pendahuluan}

Islam mengajarkan kepada umatnya untuk berbuat dan berkelakuan baik dalam hal apapun. Tidak memungkiri dalam hal pernikahan Islam juga memberikan peraturan yang baik juga, peraturan yang baik ini diperuntukkan kepada umatnya supaya tidak terjerumus terhadap hal-hal yang tidak diinginkan (kejahatan). Dalam hal pernikahan pun juga diberikan aturan. Hal ini semata demi kebaikan kehidupan umat manusia didunia dan di akhirat.

This work is licensed under Creative Commons Attribution Non Commercial 4.0 International License Available online on: http://riset.unisma.ac.id/index.php/fai/index 
Pernikahan menjadi hak setiap orang. Negara menjamin warga negara untuk membentuk rumah tangga melalui perkawinan yang sah. Negara pun telah mengatur bagaimana agar sebuah perkawinan dapat dilakukan secara sah. Bukan hanya itu, negara juga menata aturan agar semua pernikahan dicatat. Sehingga jalinan pernikahan itu memiki perlindungan hukum, baik di dalam maupun di luar pengadilan.

Untuk tercapainya sebuah akad nikah yang sah, negara mengakomodasi ketentuan yang ada dalam hukum Islam (fikih). Akad nikah harus dilakukan oleh wali yang sah, disaksikan dua orang saksi laki-laki, ada mempelai yang akan menikah, serta ada ijab dan kabul yang akurat. Selain rukun nikah, keabsahan sebuah akad nikah juga harus memperhatikan ketentuan mengenai larangan nikah yang telah diatur secara rinci dalam Undang-Undang Perkawinan dan Kompilasi Hukum Islam.

Pernikahan atau perkawinan merupakan salah satu syariat Islam. Allah menyebutkan menikah adalah ibadah untukmenyempurnakan agama. Pernikahan dalam Islam disebut sebagai penjagaan (perlindungan) bagi manusia dari fitnah dan pandangan serta hal -hal yang diharamkan yang bisa dilakukan oleh dua insan yang bebeda jeis kelaminnya. Pernikahan sangat dianjurkan oleh agama untuk manusia dalam memenuhi kebutuhan biologisnya, namaun dalampernikahan juga terdapat komponen-komponen yang ada di dalamnya yang harus dipenuhi sehingga pernikahnnya menjadi sah, salah satunya ialah dengan adanya wali nikah yang akan menikahkan kedua belah pihak.

Aturan yang ada dalam pekawinan antara lain adanya wali. Wali dalam perkawinan menjadi syarat sahnya pernikahan. Wali juga menjadi rukun dalam pernikahan hal ini sesuai dengan pendapat sebagian besar Ulama dan para sahabat Nabi. Aisyah RA berkata bahwa Rasulullah bersabda bahwa wanita manapun yang menikah tanpa seizin walinya maka nikahnya adalah batal (tidaklah sah), nikahnya batal,nikahnya batal. Abu Daud juga mengatakan Rasulullah SAW bersabda "tidaklah sah nikah kecuali dengan adanya wali". Dari pernyataan tersebut jelaslah pentingnya wali dalam pernikahan. Adanya wali dari pihak prempuan. Seorang wanita diharamkan untuk menikakan dirinya sendiri. Menikah tanpa adanya wali bagi seorang perempuan akan menjadika pernikahnnya tidak sah. Tidak diizinkn selain wali sbagai wali dari pernikahan tersebut.

Dalam praktiknya, untuk menyelenggarakan akad nikah yang sempurna, kadang kala terbentur kendala. Salah satunya adalah saat wali nasab yang berhak, berada di tempat yang berbeda. Jauh dari tempat pelaksanaan akad nikah, sehingga tidak dapat hadir. Hal ini dapat terjadi karena beberapa alasan. Bisa jadi karena kondisi alam, misalnya sedang terjadi bencana, sehingga wali nasab yang

JAS: Volume 2 Nomor 2, 2020 
sedang berada di luar daerah tidak dapat hadir saat akad nikah. Atau karena tibatiba sakit sehingga tidak bisa berangkat menuju tempat akad. Atau karena sang mempelai wanita sedang merantau meninggalkan kampung halaman. Bisa juga karena tenyata orang tua mempelai wanita ini telah bercerai. Akibatnya sang ayah tinggal di tempat yang berbeda. Kebersamaan pun sudah jarang terjadi. Sehingga saat anaknya akan menikah, sang ayah yang merupakan wali nasabnya, tidak ada di tempat. Dan banyak lagi keadaan lain yang melatarbelakangi terjadinya keadaan wali nasab jauh atau tidak hadir saat akad nikah.

Berasal dari banyaknya pernikahan yang tidak sah sehingga menimbulkan pernikahan terhadap anak turunnya tidak sah juga, apalagi dalam pernikahan yang tidak sah yang kemudian menghasilkan anak perempuan, dimana dalam pernikahan anak perempuan sangat membutuhkan adanya wali. Seorang perempuan tidak akan sah pernikahannya tanpa adanya wali, hal ini dikarenakan seorang wanita gampang terbawa persaannya, oleh akrena itu seorang wali sangatlah dibutuhkan dalam pernikahan. banyaknya para pekerja wanita yang kebanyakan pendidikannya yang kurang sehingga banyak para wanita yang bekerja sebagai pembantu di luar negeri, dan ternyata setelah pulang kampung tidak jarang dari merka (para pekerja wanita) membawa anak dari hasil perkawinannya diluar negeri, entah itu diketahui oleh sang keluarganya, entah itu tidak, namun, kebanyakan dari mereka (para pekerja wanita) banyak yang melakukan pernikahan ditempat mereka bekerja tanpa diketahui oleh keluarganya, meskipun keluarga yang berhak untuk menjadi walinya masih ada. Disisi lain tidak jarang juga mereka (para pekerja wanita) menikah dengan sesama para pekerja yang tidak jelas asal-usulnya dan yidak jelas juga keberadannya. Hal ini akan menjadi masalah juga ketika anak yang dilahirkan dari hasil perkawinan tersebut adalah perempuan. Kejadian pernikahan seperti itu banyak sekali, meskipun diantara mereka telah mendapatkan surat nikah, namun surat nikah yang di berikan setelah di cek, kebanyakan adalah surat nikah abal-abalan. tidak jarang juga wanita yang bekerja ke luar negeri telah mendapatkan anak dari hasil hubungan dengan sang majikan, ketika pulang mereka membawa anak, lalu tidak bisa menuntut terhadap majikannya untuk menjadi wali nikah ketika sang anak telah dewasa, apalagi jika pernikahannya melulaui agama yang berbeda, hal ini akan menjadikan repot, siapakah yang berhak menjadi wali atas pernikahan anak perempuan tersbut jika ayah kandungnya adalah majikan ibunya dan sang ayah berbeda agama.

Jika ada seorang laki-laki yang merantau kemudian menikah dengan wanita, dan sang laki-laki tersebbut menikah tidak hanya satu kali, setelah menikah, menghasilkan anak kemudian dia pindah tempat/ menghilang dan keberadannya 
tidak dapat diketahui. Ketika dari hasil perkawinan mendapatkan seorang anak perempuan, siapakah yang berhak menjadi wali dari anak perempuan tersebut. pada zaman sekarang banyaknya wanita yang tidak lagi berstatus gadis, meskipun tanpa diketahui oleh orang banyak, namun para wanita tersebut di hukumi janda atau gadis.

Ketika ada seorang Wanita yang hilang keperawannya dengan perzinahan bagaimanakah hukum perkawinan berikutnya. ketika ada anak gadis yang masih dibawah umur ingin menikah, namun yang menjadi wali nikah adalah kakeknya, bukan ayah kandungnya, padahal ayah kandungnya masih ada dan kuasa atas perwaliannya. Dari latar belakang keadian-kejadian diatas maka Peneliti berinisiatif untuk membahasnya dan memberikan penjelasan dalam hal perwalian dalam pernikahan, sehingga peneliti memilih judul "Tidak sah perwalian karena tidak sah perkawinan".

\section{B. Metode}

Dalam penulisan artikel ilmiah ini, penulis menggunakan metode kualitatif. Metode ini Bersifat lebih ke arah metode kajian atas gagasan konseptual. Sedangkan data yang dikumpulkan dan yang akan dianalisis bertumpu pada ketersediaan sumber data di perpustakaan (Library Research).Teknik analisis data yang digunakan dalam kajian ini adalah teknik analisis isi (Content Analysis), yaitu sebuah teknik analisis yang secara komprehensif berusaha menggali beragam keterangan dari pesan atau informasi yang disajikan dalam wujud lambang atau simbol tertentu yang terdokumentasikan. Sedang gambar data penelitian ini diperoleh dari beragam sumber yang bersifat kekinian dengan tidak meninggalkan referensi klasik.

\section{Hasil dan Pembahasan}

Menururt Sayyid Sabiq dalam bukunya fiqih sunnah Wali ialah suatu ketentuan hukum yang dapat dipaksakan kepada orang lain sesuai dengan bidang hukumnya (Sabiq, 1990: 11) Wali ada yang umum dan ada yang khusus. Yang khusus ialah berkenaan dengan manusia dengan manusia dan harta benda. Disini yang dibicarakan wali terhadap manusia, yaitu masalah perwalian dalam perkawinan. Perwalian menurut bahasa yakni berarti cita atau pertolongan. Namun menurut syariat perwalian adalah menyerahkan perkatan kepada orang lain dan pengawasan atas keadaannya.

Perwalian dalam pernikahan bisa dikatakan suatu kekuasaan atau wewenang syar'i atas segolongan manusia yang dilimpahkan kepada orang yang

JAS: Volume 2 Nomor 2, 2020 
sempurna, karena kekurangan tertentu pada orang yang dikuasai itu demi kemaslahatannya sendiri

Syarat-syarat wali : adapun yang menjadi syarat sebagai wali ialah :

1. Merdeka (seorang budak tidaklah syah untuk menikahkan anaknya atau anggota keluarganya, meskipun ia beragama Islam, berakal dan Balih,seorang budak tidaklah mempunyai hak atas perwalian baik atas dirinya sendiri ataupun orang lain)

2. Berakal sehat (seorang yang ideot dan orang yang kurang waras atau gilatidaklah untuk menjadi wali bagi anak gadisnya, dalam hal ini meskipun gilanya datangnya kadang-kadang).

3. Dewasa dalam hal ini bisa disebut dengan baligh (waliadalh seseorang yang dipasrahi urusan orang lain, dimana dalam hal ini adalah urusan seorang perempuan yang akan menikah, tidaklah mungkin menyerahkan urusan pernikahan terhadap anak-anak yang masih kecil), baik itu yang menganut agama Islam atau bukan. Budak, orang gila, dan anak kecil tidak dapat menjadi wali karena orang- ornag tersebut tidak berhak mewalikan dirinya sendiri apalagi terhadap orang lain. Sebagian fuqoha juga menambahkan syarat wali yang berikutnya yaitu seorang yang 'adalah yaitu bukan seorang yang pendosa, pencuri, berzina, meminum khamr, pembunuh, pemakan harta anak yatim, dan sebagainya, selain itu dia telah menghindaru dari dosa-dosa kecil dan perbuatan-perbuatan yang tidak sepantasnya. Hal ini diungkapkan oleh Ulama Hambaliah dan merupakan pendapat yang kuat dari Madzhab Sayafi'i, adapun Ulama Hanafi berpendapat bahwa seorang pendosa tidaklah hlang haknya sebagai wali kecuali telah melampaui batas dan dilakukan secara terang-terangan. Hal ini juga diungkapkan oleh ulama Malikiyah yang berpendapat seorang pendosa tidaklah hilang haknya sebagai wali.

4. Beragama Islam, jika yang dinikahkan adalah orang yang beragama Islam, maka yang menjadi wali adalah uga yang beragama Islam. Orang Islam tidak bisa menjadi wali atas orang yang bukan beragama Islam, begtu juga sebaliknya.

5. Sebagian ulama berpendapat untuk menjadi seorang wali tidak dalam keadaan ihram,haji ataupun umroh.

Dari definisi tersebut jelaslah bahwa untuk menjadi seorang wali dalam pernikahan tidaklah sembarangan melainkan harus memenuhi syaratnya. Dalam hal perwalian ini orang Islam hanya dapat diwalikan oleah orang Islam, orang yang selain islam hanya dapat/ sah diwalikan oleh orang bukan Islam atau dengan kata lain syarat menjadi wali dan yang diwalikan haruslah seagama.

JAS: Volume 2 Nomor 2, 2020 
Dalam KHI di jelaskan bahwa Wali nikah dalam perkawinan merupakan rukun yang harus dipenuhi bagi calon mempelai wanita yang bertindak untuk menikahinya (Diretorat Pembinaan Badan Peradilan agama. 1992: 19). Wali nikah adalah : sebutan untuk pihak laki-laki dalam keluarga atau lainnya yang bertugas mengawasi keadaan atau kondisi seseorang perempuan, termasuk dalam pernikahan. Dalam pernikahan Islam wali nikah adalah orang yang menikahkan perempuan dengan laki-laki yang sesuai dengan aturan Islam.

Wali dalam pernikahan memiliki peranan yang sangat penting . bahkan dalam pernikahan, sah atau tidaknya pernikahan juga ditentukan oleh adanya wali, karena pernikahan dalam Islam tanpa adanya wali tidaklah sah atau batal. Menurut KHI Wali hakim adalah : wali nikah yang ditunjuk oleh Menteri agama atau pejabat yang ditunjuk olehnya, yang diberi hak dan kewenangan untuk bertindak sebagai wali nikah (Diretorat Pembinaan Badan Peradilan agama. 1992: 11). Menurut KHI Perwalian adalah : kewenangan yang diberikan kepada seseorang untuk melakukan sesuatu perbuatan hukum sebagai wakil untuk kepentingan dan atas nama anak yang tidak mempunyai kedua orangtua atau kedua orangtua atau orang tua yang masih hidup, tidak cakap melakukan perbuatan hukum (Diretorat Pembinaan Badan Peradilan agama. 1992: 12).

Dalam KHI Yang bertindak sebagai wali nikah ialah seorang laki-laki yang memenuhi syarat hukum Islam yakni : muslim, aqil (berakal) dan baligh (Diretorat Pembinaan Badan Peradilan agama. 1992: 20). Lantas siapakah mereka yang berada dibawah perwalian? Adapun anak yang berada dalam perwalian adalah:

a. Anak sah yang kedua orangtuanya telah dicabut kekuasannya sebagai orang tua.

b. Anak sah yang kedua orang tuanya telah bercerai

c. Anak yang lahir diluar perkawinan

Konsep persyaratan adanya wali nikah perempuan dalam perspektif fiqh.

Jumhur ulama, termasuk didalamnya sa'id bin Musayyib, Hasan Al Bashri, abdullah bin Abdul aziz, Ats-Tsauri dan Imam Syafi'i mereka berpendapat bahwa pernikahan tana adanya wali tidaklah sah. Karena kehadiran seorang wali adalah salah satu rukun nikha yang harus dipenuhi, namun selain itu Imam syafi'i juga berpendapat bahwa seorang wali dilarang untuk mempersulit pernikahan wanita yang berada dibawah kekuasaannya selama wanita dan laki-laki yang menikahinya yaitu sekufu.

Sedangkan menurut Imam Maliki berpendapat bahwa ika seorang wanita akan menikah maka harus ada izin dari wali atau wakil yang terpandanf atau hakim untuk melkasanakan akad nikah, namun Imam Maliki tidak menjelasakan wali harus hadir dalam akad nikah tersebut, akan tetapi meskipun demikian Imam

JAS: Volume 2 Nomor 2, 2020 
Malik tidak membolehkan wanita untuk menikahkan dirinya. Sedangkan menurut Ibnu Qudamah dari Madzhab Hambali berpendapat bahwa wali harus ada dalam perkawinandengan kata lain wali nikah harus hadir dalam akad nikah.

Sedangkan Abu Hanifah berpendapat bahwa menikah tanpa adanya wali itu hukumnya boleh dengan kata lain wanita boleh menikahkan dirinya sendiri. Atau boleh meminta orang lan diluar wali nasab untuk menikahkan nya (gadis atau janda). Namun jika tidak sekufu, maka wali boleh membatalkannya. Dalam KHI Wali nikah terdiriri dari : wali nasab dan wali hakim (Diretorat Pembinaan Badan Peradilan agama. 1992: 20).

Namun referensi lain menyebutkan macam macam wali yakni wali nasab, wali maula, wali tahkim dan wali hakim. Wali nasab ialah wali nikah dimana wali tersebut ada hubungan darah dengan wanita yang akan dinikahkan. Wali maula ialah wali nikah dimana wali tersebut telah membebaskan wanita yang akan dinikahkannya. Dalam hal ini wanita tersebut yang awalnya hamba sahaya (budak) yang merdeka jika dia ingi menikah, maka yang akan menjadi walinya adalah orang yang mmemerdekakannya. Dengan kata lain, wali maula adalah wali yang menikahkan budaknya. Dan apabila wali maula tersebut telah tiada maka yang akan menjadi wali maula adalah keluarga atau ashabah dari orang yang telah memerdekakannya. Wali tahkim yaitu wali yang diangkat oleh calon memepelai suami atau calon istri.

Wali nasab terdiri dari empat kelompok dalam ururtan kedudukan, kelompok yang satu didahulukan dari kelompok yang lain sesuai erat tidaknya susunan kekerabatan dengan calon mempelai wanita,

1. Pertama : kelompok kerabat laki-laki garis lurus keatas yakni ayah, kakek dari pihak ayah dan seterusnya.

2. Kedua : kelompok kerabat saudara laki-laki kandung atau saudara laki-laki seayah, dan keturunan laki-laki mereka

3. Ketiga : kelompok kerabat paman, yakni saudara laki-laki kandung seayah, saudara seayah dan keturunan laki-laki mereka.

4. Keempat, kelompok saudara laki-laki kandung kakek, saudara laki-laki seayah kakek dan keturunan laki-laki mereka.

Apabila dalam satu kelompok wali nikah terdapat beberapa orang yang sama-sama berhak menjadi wali, maka yang paling berhak menjadi wali ialah yang lebih dekat derajat kekerabatannya dengan calon mempelai wanita Apabila dalam satu kelompok sama derajat kekerabatannya maka yang paling berhak menjadi wali nikah ialah kerabat kandung dari kerabat yang hanya seayah. Apabila dalam satu kelompok, deraat kekerabatannya sama yakni sama-sama derajat kandung, atau sama-sama derajat kerabat seayah, mereka sama-sam berhak menjadi wali 
nikah, dengan mengutamakan yang lebih tua dan memenuhi syarat-syarat wali. Menurut Sayyid Sabiq dalam bukunya fiqih sunnah Wali pernikahan adalah ahli waris, tetapi bukan paman dari Ibu, bibi dari Ibu, saudara seibu dan keluarga Dzawil arham. Hal ini diungkapkan oleh Jumhur Ulama seperti : Malik, Tsauri Laits, dan Syafi'i (Sabiq, 1990: 22).

Syafi'i berkata nikah seorang wanita tidak dapat dilakukan, kecuali dengan pernyataan wali qarib (wali dekat), jika ia tidak ada, dengan wali yang jauh, jika tidak ada maka menggunaan wali hakim. Wali pernikahan selalu diambil dari pihak ayah hal ini sesuai dengan aturan nasab (pertalian keluarga yang didasarkan pada akad pernikahan yang sah). Seorang anak bernasab terhadap kepada ayahnya, oleh karena itu yang wajib menikahkan adalah para orang yang sedarah dengan perempuan dari ikatan pernikahan yang sah secara jelas. Ayah angkat tidaklah bisa menikahkan anak angkatnya hal ini disebabkan oleh sang ayah angkat tidaklah memiliki hubungan kerabat kandung atau sedraah dengan anak angkatnya.

Namun jika seorang anak tidak diketahui silsilah keluarganya maka hakim pengadilanlah yang bisa memutuskan bahwa wali nikah anak tersebut adalah ayah angkat anak tersebut untuk menikahkannya. Namun jika dalam kasus seperti ini ayah angkatnya meninggal dunia maka hakimlah atau orang yang diberi kuasa untuk menikahkan anak tersebut. Daftar urutan wali diatas tidaklah boleh diacak atau dilangkahi. Misalkan apabila ayah kandung masih hidup, maka tidaklah boleh hak kewaliannya dilangsungkan oleh kakeknya atau kepada yang lain, kecuali ada izin atau udzur yang lain sehngga sang ayah memberikan haknya terhadap mereka (urutan setelahnya).

Jika terdapat beberapa orang yang dalam hubungannya berasal dari jalur yang sama, maka yang berhak atau yang didahulukan adalah yang lebih dekat kedudukannya. Misalkan jika ada ayah dan kakek, maka yang didahulukan adalah ayah. Barulah kemudian jika ayahnya tidak ada maka bebrapa orang kedudukannya sama, misalkan saudara kandung dengan saudara sebapak, maka yang lebih dahulu yaitu saudara kandung. Lebih didahulukannya seorang yang lebih dekat dalam menjadi wali dalampernikahan disebabkan orang yang palng dekat adalah yang paling paham dan paling kasih sayang kepada wanita yang akan dinikahkan tersebut. Selain itu orang yang mendapatkan wasiat (wakil) dari ayahnya untuk menikahkan anaknya karena posisinya sebagaimana bapaknya. Selanjutnya adalah kakek dari bapak kemudian ke atasnya. Dengan mendahulukan yang paling dekat, karena wanita yang akan dinikahkannya adalah keturunannnya. Dalam kasus seperti ini seorang kakek posisinya sama dengan bapaknya,setelah kakek adalah anak siwanita jika sang wanita tersebut adalah janda kemudian keturunan laki-lakinya.

JAS: Volume 2 Nomor 2, 2020 
Selanjutnya jika tidak ada antara ayah, kakek ke atas,dan anak, maka saudara sekandung yang akan menggantikkan untuk menjadi wali, saudara lakilaki sekandung kedudukannya lebih dekat dari pada saudara laki-laki seayah. Jika tidak ada maka barulah paman dari ayah (saudara kandung bapak). Saudara kandung bapak kedudukannya lebih dekat dari pada saudara kandung bapak yang sayah. kemudian jika orang-orang tersbut tidaklah ada, maka seorang yang memerdekakannya dari perbudakan. Dalam hal ini jelaslah budak dapat diwali nikahkan oleh orang yang memerdekakannya. Jika keseluruhan orang tersebut tidaklah ada, maka yang akan menjadi wali nikah dalam pernikahannya adalah hakim atau orang aang mewakili (pegawai KUA resmi setempat).

Seuai dengan urutan yang menjadi wali dalam pernikahan diatas, maka apabila wali yang dekat masih ada, maka tidaklah boleh mendahulukan wali yang jauh.apabila ada wali yang jauh menikahkan seorang wanita dan wali yang dekat masih ada dan berada ditempat, sedangkan wanita tersbut bersedia dinikahkan, sementara wali yangdekattidak mengizinkan, maka pernikahannya tidaklah sah. Pendapat ini menurut Imam Syafi'i. Hal ini disebabkan oleh wali yang jauh tidak lah berhak menikahkan wanita tersebut selama wali yang dekat masih ada, dan tidak ada udzur, hal ini sebagaimana sesuai dengan hukum wrisan yakni keluarga yang lebih jauh tidaklah berhak selama keluarga yang dekat masih ada.

kedudukan wali nasab tidak bisa bergeser ke wali nasab yang lain. Seperti karena karena ayah kandung jauh, lalu digeser ke kakek kandung dan seterusnya. Hal ini adalah praktik yang keliru. Sebab wali nasab yang paling berhak itu masih ada. Peralihan dari seorang wali nasab ke wali nasab berikutnya secara hirarkis itu berlaku dalam keadaan wali nasab yang paling berhak, ternyata tidak memenuhi syarat. Baik karena tidak muslim, atau masih belum akil-baligh, atau karena mengalami gangguan fisik dan/atau mental. Atau karena wali yang paling berhak itu sudah meninggal.

Selama wali yang berhak itu ada, maka ia harus diutamakan, meskipun ia jauh. Sebab ada kemungkinan wali nasab yang paling berhak itu enggan untuk menikahkan perempuan yang ada dalam perwaliannya dengan berbagai macam alasan. Sehingga jika kemudian bergeser ke wali nasab berikutnya, maka tidak ada artinya hak wali nasab yang paling berhak tadi. Oleh karena itu, tradisi hukum Islam sangat memproteksi hak menjadi wali nikah itu. Dalam keadaan wali nasab enggan ('adhal), maka negara yang harus menengahinya dengan jalan diajukan permohonan penetapan kea'dhalan wali kepada hakim, untuk kemudian wali nikah dilakukan oleh wali hakim. Hal ini menunjukkan, pergeseran wali itu tidak mudah terjadi, apalagi hanya karena jarak yang jauh. Padahal wali nasab yang jauh tadi, dalam keadaan memenuhi syarat menjadi wali nikah. 
Jika ditelusuri berbagai pandapat ulama terutama kalangan Syafi'iyah, maka ditemukan ketentuan bahwa wali yang jauh yang diukur dengan standar masafat qashr, harus diganti oleh wali hakim. Dan tidak dibenarkan perwalian dilakukan oleh wali nasab yang lain. Hal ini karena kewenangan wali nasab yang sedang tidak berada di tempat akad itu, tetap ada. Hanya saja ia sulit untuk melaksanakan kewenangannya karena jarak yang jauh, oleh karana itu wali hakimlah yang berwenang untuk menggantikan.

Ketentuan fikih Syafi'iyah cenderung melegalisasi peran wali hakim menggantikan wali nasab yang berhak hanya karena jarak qashr. Padahal, kenasaban antara wali dan perempuan yang berada dalam walayahnya, terjalin berdasarkan pada kefitrahan hubungan manusia yang diciptakan Allah swt. Sehingga antara satu manusia dan manusia lainnya dalam ikatan kenasaban sedemikian itu, tidak bisa melepaskan dirinya dari hak dan kewajiban yang terjalin bersamaan dengan terjalinnya hubungan nasab tersebut, termasuk dalam hal ini adalah mengenai kewalian dalam nikah.

Jika ditelaah dari adanya ketentuan mengenai kewenangan wali hakim (sulthan) yang menggantikan wali nasab, maka diketahui bahwa esensi legalitas kewenangan wali hakim (sulthan) itu muncul lantaran fungsi izin dan persetujuan wali nasab sebagai simbol penanggung jawab (pemegang kuasa) seorang perempuan, tidak dapat diketahui. Hal ini senada dengan yang disebut Imam as Syairaziy saat menjawab persoalan wali yang berada masih dalam radius hadir bukan qashr, sebagai berikut:

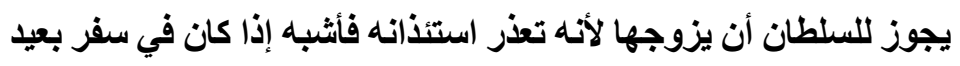

Artinya: "wali hakim boleh menikahkan perempuan tersebut karena sulit mengetahui dan meminta izin wali nasabnya, sebagaimana kondisi ini sama dengan kondisi dalam perjalanan yang jauh"

Menurut nalar fikih kala itu, ketidakmungkinan untuk diketahui itu dapat terjadi karena jarak yang jauh yang diacu dengan standar jarak qashr, atau karena wali enggan untuk menikahkan anaknya. Dengan demikian, logika hukum yang sedang dibangun dari ketentuan peran wali hakim ini, adalah pada aspek sulitnya mengetahui izin atau sikap wali nasab terhadap pernikahan perempuan yang berada dalam walayahnya.

Logika atau sebut saja illat kewenangan wali hakim ini tentu sudah tidak ditemui lagi dalam konteks saat ini. Artinya, meskipun wali nasab jauh, keadaan jauh itu tidak bisa lagi menjadi alasan bolehnya wali hakim untuk 
menggantikannya. Sebab saat ini, sangat mudah untuk mengetahui izin wali yang berada di tempat yang jauh dengan cara-cara tertentu berbasis pada kemajuan teknologi, seperti surat-menyurat, telepon, video call, dll

Selanjutnya, untuk akad nikah dapat dilakukan dengan cara tawkil seperti biasa, dengan perantara penghulu yang dipercaya. Peran penghulu di sini tentu hanya sebagai wakil, bukan sebagai wali. Karena wali tetap diduduki oleh wali nasab yang jauh tersebut. Hanya saja, agar praktik sedemikian ini tidak mengurangi sakralitas akad nikah, dan agar tertib administrasi, maka Kementerian Agama telah mengeluarkan ketentuan tentang hal ini berupa Peraturan Menteri Agama Nomor 19 Tahun 2018 tentang Pencatatan Perkawinan. Dalam Pasal 11 Ayat (5) disebutkan beberapa teknis yaitu:

"dalam hal wali tidak hadir saat akad nikah, wali harus membuat surat taukil wali yang ditandatangani oleh wali dan disaksikan dua orang saksi dan diketahui oleh Kepala KUA tempat tinggal wali“. Dengan demikian, perempuan yang akan menikah tetapi wali nasabnya jauh, idealnya harus tetap mendudukkan wali nasabnya yang jauh itu sebagai wali nikah. Kemudian wali nasabnya tadi bertawkil atau membuat akad wakalah disaksikan oleh dua saksi, kepada penghulu/atau orang lain yang dipercaya di tempat akad nikah dilangsungkan.

Proses tawkil ini diformat dalam bentuk surat yang difasilitasi oleh Kepala KUA tempat tinggal wali nasab, untuk kemudian dikoordinasikan kepada Kepala KUA tempat akad nikah dilangsungkan. Dalam KHI Pasal 22 menjelaskan: Apabila wali nikah yang paling berhak, urutannnya tidak memenuhi syarat sebagai wali nikah atau oleh karena wali nikah itu menderita tuna wicara, tuna rungu, atau sudah udzur, maka hak menjadi wali bergeser kepada wali nikah yang lain menurut derajat berikutnya (Diretorat Pembinaan Badan Peradilan agama. 1992: 20).

Namun jika yag akan menjadi wali dalam daftar urutan tersebut sudahlah tidak ada atau sudah tidak memungkinkan, maka jalan terakhir untuk menjadi wlai dalam pernikahan adalah dengan memakai wali hakim, wali hakim baru bisa digunakan jika memang wali sahnya tidak ada yang bisa menikahkannya. Wali hakim adalah para kepala pemerintahan (kholifah, Raja, Presiden, Perdana Menteri) yang berkuasa didaerah tersebut dengan cara menjadi menjadi wali secara langsung atau mewakilkannya kepada pejabat yang ditunjuk, di Indonesia berarti presiden sebagai wali hakimnya, kemudian Presiden dapat mengangkat para pembantu secara resmi dalam menjalankan tugas sebagai wali pernikahan ini. Biasanya yang menjadi wakilnya dalam hal ini adalah menteri agama dan para pembantunya kemudia turun hingga para pemimpin dikantor wilayah kementrian

JAS: Volume 2 Nomor 2, 2020 
agama dan kantor urusan agama yang biasa kita sebut dengan KUA di daerahnya masing-masing.

Dengan kata lain wali hakim adalah penguasa tempat dimana calon mempelai akan melangsungkan perikahan. Menurut HR Ahmad, Abu Daud, Ar Tirmidzi sultan adalah wali bagi mereka yang tidak memiliki wali. Para penguasa mempunyai hak untuk menikahkan akan tetapi setelah kerabat atau dengan kata lain wali khususnya tidak ada. Menurut Ibnu Qudamah : sultan atau pemimpin dalam perwalian pernikahan adalah pemimpin, hakim atau orang yang dipasrahi untuk menangani maslah pernikahan. Sayyid Sabiq dalam bukunya fiqih sunnah menyatakan bawa Wewenang wali berpindah ke tangan wali hakim, apabila:

1. Ada perteentangan diantara wali-wali

2. Bilamana walinya tak ada dalam pengertian tidak adayang absolut (mati, hilang) atau karen ghaib.

Bila datang datang laki-laki yang sepadan dan melamar kepada wanita yang sudah baligh dan ia menerimanya, tetapi tak seorangpun dari walinya yang hadir pada waktu itu, misalnya karen ghaib, meskipun tempatnya dekat, tapi diluar fihak perempuan. Maka siapakah yang akan menikahkannya?dalam keadaan seperti ini hakim berhak meng'aqadkannya, kecuali kalau perempuan dan laki-laki yang mau kawin tersebut bersedia menanti kedatangan walinya yang ghaib itu. Hal seperti ini (menanti) adalah hak bagi perempuan, sekalipun waktunya masih lama. Jika laki-laki dan perempuan tidak mau menanti, tak ada alasan untuk mengharuskan mereka menanti (Diretorat Pembinaan Badan Peradilan agama. 1992: 30).

Dalam KHI Pasal 23 dijelaskan:

1) Wali hakim baru dapat bertindak sebagai wali nikah apabila wali nasab tidak ada atau tidak mungkin menghadirkannya atau tidak diketahui tempat tinggalnya atau gaib atau adlal atau enggan.

2) Dalam hal wali adlal atau engan maka wali hakim baru dapat bertindak sebagai wali bikah setelah ada putusan pengadilan agama tentang wali tersebut (Diretorat Pembinaan Badan Peradilan agama. 1992: 22).

Dalam KHI Pasal 107 dijelaskan:

1. Perwalian hanya terhadap anak yang belum mencapai umur 21 tahun dan atau belum pernah melangsungkan perkawinan

2. Perwalian meliputi perwalian terhadap diri dan harta kekayaannya.

3. Bila wali tidak mampu berbuat atau lalai melaksanakan tugas perwaliannya, maka pengadilan Agama dapat menunjuk salah seorang kerabat untuk bertindak sebagai wali atas permohonan kerabat tersebut.

JAS: Volume 2 Nomor 2, 2020 
4. Wali sedapat-dapatnya diambil dari keluaga anak tersebut atau orang lain yang sudah dewasa, berpikiran sehat, adil, jujur dan berkelakuan baik, atu badan hukum.

Adil yang diamksud dalam hal ini adalah tidak memihak terhadap salah satu calon pengantin, serta seorang muslimyang dapat menjaga diri dan martabatnya. Menurut Saayid Sabiq Dalam hal ini disisi lain wali tidak disyaratkan adil. Seorang yang durhaka tidak kehilangan hak menadi wali dalam perkawinan, kecuali kedurhakaannya melampaui batas kesopanan yang berat, karena wali tersebut tidak menentramkan jiwa orang yang diurusnya, karena itu khaknya menjadi wali menjadi hilang (Diretorat Pembinaan Badan Peradilan agama. 1992: 22). Dalam KHI Pasal 108 dijelaskan:

Orang tua dapat mewasiatkan kepada seseorang atau badan hukum untuk melakukan perwalian atas diri dan kekayaan anak atau anak-anak nya sesudah ia meninggal dunia. Dalam KHI Pasal 109 dijelaskan: Pengadilan agama dapat mencabut hak perwalian seseorang atau badan hukum dan memindahkannya kepada pihak lain atas permohonan kerabatnya bila wali tersebut pemabok, penjudi, pemboros, gila dan atau melalikan atau menyalahgunakan hak dan wewenangnya sebagai wali demi kepentingan orang yang berada dibawah perwaliannya. Dalam KHI Pasal 110 dijelaskan:

1. Wali berkewajiban mengurus diri dan harta orang yang berada dibawah perwaliannya dengan sebaik-baiknya dan berkewajiaban memberikan bimbingan agama, pendidikan dan ketrampilan lainnya untuk masa depan orang yang berada dibawah perwaliannya.

2. Wali dilarang mengikatkan, membebani dan mengasingkan harta orang yang berada di bawah perwaliannya, kecuali bila perbuatan tersebut menguntungkan bagi orang yang berada dibawah perwaliannya atau merupakan suatu kenyataan yang tidak dapat dihindarkan.

3. Wali bertanggung jawab terhadap harta orang yang berada di bawah perwliannya, dan mengganti kerugian yang timbul sebagai akibat kesalahan atau kelalaiannya.

4. Dengan tidak mengurangi ketentuan yang diatur dalam pasal 51 ayat (4) undang-undang No. 1 tahun 974, pertanggungawaban wali tersebut ayat (3) harus dibuktikan dengan pembukuan yang ditutup tiap satu tahun sekali.

Dalam KHI Pasal 111 dijelaskan:

1. Wali berkewajiban menyerahkan seluruh harta orang yang berada dibawah perwalian anya, bila yang bersangkutan telah mencapai umur 21 tahun atau telah kawin.

JAS: Volume 2 Nomor 2, 2020 
2. Apabila perwalian telah berakhir, maka Pengadilan Agama berwenang mengadili perselisihan antara wali dan orang yang berada di bawah perwaliannya tentang harta yang diserahkan kepadanya.

Dalam KHI Pasal 112 dijelaskan:

Wali dapat mempergunakan harta orang yang berada dibawah perwaliannya, sepanang diperlukan untuk kepentingan menurut kepatutan atau bul ma'ruf kalau wali itu fakir (Diretorat Pembinaan Badan Peradilan agama. 1992: 53).

Menurut Sayyid Sabiq dalam bukunya fikih sunnah Apabila perkawinan gadis dibawah umur, ayah kandung dan kakeknya boleh mengawinkan mereka tanpa persetujuan nya. Sebab anak gadis yang dibwah umur tersebut belum mempunyai pendapat, sehingga ayah kandung dan kakeknya lah yang mengurus dan memelihara haknya (Sabiq, 1990: 20). Selain itu anak gadis yang masih anakanak persetujuannya belum dianggap sempurna. Dan sesudah baligh tidak mempunyai khiyar (menolak atau menerimanya).

Golongan syafi'i menganjurkan agar ayah dan kakek tidak mengawinkan wanita yang masih dibawah umur / anak-anak sehingga ia cukup dewasa dan dengan seizinnya. Agar si anak nantiya tidak terjatuh pada pria yang tidak disukai. namun kebanyakan ulama berpendapat bahwa wali selain ayah kandung dan kakeknya tidak boleh mengawinkan wanita yang masih anak- anak . dan jika hal ini terjadi, maka hukumnya tidak sah, namun Abu Hanifah, auzai dan golongan ulama salaf membolehkan dan perkawinannya sah, akan tetapi si wanita telah baligh dan berhak khiyar. Dalam hal ini tidak harus menunggu sampai 21 tahun.

Sebagaimana yang dijelaskan diatas bahwa wali menjadi salah satu syarat sahnya menikah, jika ada seseorang yang ingin menikah tanpa adanya wali para ulama berbeda pendapat, yakni pendapat ulama sunni (ahlus sunnah wal jama'ah) dan pendapat syi'i (syi'ah). Ulama sunni mempunyai 6 pendapat tentang hukumnya nikah tanpa adanya wali yakni :

1. Pendapat yang memandang bahwa sigat akad nikah yang diucapkan oleh wanita yang dewasa yang cerdik adalah sah secara mutlaq. Yang dimaksud mutlaq dalam hal ini adalah baik wanita itu gadis maupun janda, sepupu dengan calon suaminya atau tidak, atas izin walinya atau tidak, baik diucapkan secara langsung ataupun berwakil kepada wanita lain atau kepada laki-laki lain yang bukan walinya. Hal ini sesuai dengan pendapat Imam Abu Hanifah, abu Yusuf, Zufar, Auza'i, Muhammad bin Hasan menurut suatu riwayat, dan Imam Malik menururt riwayat Ibnu Qasim bagi wanita yang tidak mempunyai kedudukan (bukan dari keluarga terhormat, rakyat biasa).

JAS: Volume 2 Nomor 2, 2020 
2. pendapat yang memandang sigat ijab akad nikah yang diucapkan oleh wanita hukumnya sah, namun bergantung pada izin atau restu wali, dan juka tidak direstui oleh wali, akad tersebut menjadi batal. Pendapat ini menurut Ibn Sirin, Qasim bin Muhammad, Muhammad bin Hasan menurut suatu riwayat, dan Imam Ahmad menururt Qaul mukharraj.

3. Pendapat yang memandang bahwa izin wali haruslah diperoleh sebelum berlangsung akad nikah. Hal ini sesuai dengan pendapat al muhazzah, karangan Ishak asy-Syairazi dan Nail al autar. Akan tetapi dalam al-Muhalla, karya Ibn Hazm isebutkan bahwa abu Saur hanya membolehkan wanita dikawinkan oleh laki-laki muslim walaupun tidk berstatus wali, karena orang-orang mukmin itu satu dengan yang lain bersaudara, dan semata mereka saling mwalikan. Jadi menurut al-muhalla, abu Saur tidak membenarkan wanita meikahkan dirinya secara langsung walaupun telah mendapat izin walinya.

4. Pendapat yang memandang bahwa pernikahan tanpa wali itu hukumnya sah asalkan sekufu (setingkat), dan batal jika tidak sekufu (tidak setingkat) hal ini menurut ulama Asy-Sya'bi dan Az- Zuhri.

5. Pendapat yang memandang bahwa akad nikah tanpa wali hukumnya sah bagi wanita janda dan tidak sah bagi yang masih gadis, Pendapat ini menururt Daud- Az- Zahiri.

6. Pendapat yang memandang batal akad nikah yang sigat ijab nya diucapkan oleh wanita, baik gadis atau janda, sekufu atau tidak, dengan izin wali atau tidak, secara langsung untuk dirinya atau sebagai wakil. Hal ini menurut pendapat Imam Syafi'i, Imam Malik dari riwayat Asyhab, Ibn Syubrumah, Ibnu Abi Laila, sufyan Sauri, Ishaq bin Rahawaih, Ibnu Mubarak, dan Ibn Hazm.

7. Pendapat dari golongan diluar ahlus sunnah wal jamaah alam hal ini golongan syi ah yang berpendapat bahwa :

a. Syi'ah Zaidiyah yang berpendapat bahwa sigat ijab qabul akad nikah tidak sah diucapkan oleh wanita atau laki-laki yang bukan mewakili wali.

b. Syi;ah Imamiyah yang berpendapat bahwa wanita janda sah mengucapkan sigat akat nikahnya secara mutlaq, baik alam nikah abadi maupun dalam nikah sementara (Mut'ah), demikian juga gadis yang tidak mempunyai bapak (karena wafat). Golongan ini berbeda pendapat mengenai gadis yang masih hidup bapaknya, yakni: Pendapat pertama yang memandang bahwa sigat ijab akad nikah yang diucapkan oleh wanita yang masih gadis hukumnya sah secara mutlaq,baik dalam nikah 
abadi maupun nikah sementara (mut'ah). Pendapat kedua memandang bahwa sigat ijab akad nikah yang diucapkan oleh wanita gadis itu hukumny sah manakala diizinkan oleh bapaknya, demikian juga sebaliknya. Pendapat ketiga memandang bahwa sigat ijab akad nikah yang diucakan oleh wanita gadis hukumnya tidak sah secara mutlaq, yakni baik dalam nikah abadi maupun dalam nikah sementara. Pendapat keempat memandang bahwa sigat ijab akad nikah yang diucapkan oleh wanita gadis hukumnya sah dalam nikah mut'ah dan batal dalam nikah abadi. Pendapat kelima memandang bahwa sigat ijab akad nikah yang diucapkan oleh wanita gadis hukumnya sah dalam nikah abadi dan batal dalam nikah mut'ah.

Sesuai dengan yang dijelaskan diatas maka jika ada seorang wanita yang belum pernah menikah, namun dia telah melakukan perzinahan (tidak berstatus gadis), maka dalam hal ini ada dua macam peembahasan yakni :

1. Dia dianggap sebagai gadis, dalam hal ini sesuai dengan pendapat Ibnu Hazm dan Imam Malik yang berpendapat bahwa wanita yangseperti itu masih tetap dihukumi gadis, walaupun perzinahannya atas kehendak sendiri atau dengan jalan perkosaan berulang kali atau hanya satu kali, baik itu diketahui umum atau tidak,hal ini disebabkan jika wanita tersebut dikeani hukuman bad zina, maka perempuan tersebut diperlakukan seperti wanita yang masih gadis.

Disisi lain Abu Hanifah, Zaidiyah, dan kalangan Malikiyah menurut suatu qaul berpendapat bahwa wanita tersebut masih tetap dalam hukum gadis selama perzinahannya itu tidak diketahui oleh umum hal ini disebabkan sifat pemalunya masih utuh.

2. Dia dianggap sebagai janda, hal ini sesuai dengan pendapat yang dikemukakan oleh Imam Syafi'i, Hanbali, Imamiyah, serta Abu Yusuf dan Muhammad dari kalangan Hanafi yang mengemukakan bahwa seorang yang pernah melakukan perzinahan meskipun Cuma satu kali atau berulang kali , baik perzinahannya itu diketahui oleh umum maupu tidak, karena hilangnya keperawanan wanita tersebut adalah suatu kecacatan yang jika disebabkan oleh cara yang sah, maka berkuranglah nilainya, dan apabila dilakukan dengan cara yang tidak sah, maka camarlah namanya.

Disisi kasus lain ketika ada anak gadis yang masih dibawah umur ingin menikah, namun yang menjadi wali nikah adalah kakeknya, bukan ayah kandungnya, padahal ayah kandungnya masih ada dan kuasa atas perwaliannya, hukum perkawinannya seperti yang dijelaskan diatas, maka yang menjadi wali pernikahan seorang perempuan yang berstatus gadis, adalah ketika wali nasab JAS: Volume 2 Nomor 2, 2020 
nasabnya masih ada, maka walinya adalah wali nasab: yakni ayah, kakek dari pihak ayah dan seterusnya, saudara laki-laki kandung atau saudara laki-laki seayah, dan keturunan laki-laki mereka, paman, yakni saudara laki-laki kandung seayah, saudara seayah dan keturunan laki-laki mereka. saudara laki-laki kandung kakek, saudara laki-laki seayah kakek dan keturunan laki-laki mereka.

Derajat janda dan gadis didalam pernikahan status perwaliannya adalah sama, sehingga wali dalam pernikahan seorang janda ketika wali nasabnya masih ada, maka menggunakan wali nasab sebagaimana seorang gadis. Dalam pernikahannya perwalian tetap sama seperti gadis, namun dalam proses peminangannya wali tidak memiliki otoritas menerima atau menolak peminangan tersebut tanpa adanya persetujuan dari janda tersebut. Namun sebagian ulama berpendapat bahwa untuk seorang janda menikah kembali boleh melakukan pernikahan tersebut meskipun tanpa wali. Hal ini dikemukakan oleh Abu hanifah dan Dawud. Namun Jumhur Ulama berpendapat bahwa wali nikah itu berlaku untuk wanita yang masih gadis ataupun janda. Dalam pernikahan seorang janda lebih berhak terhadap dirinya daripada walinya hal ini sesuai dengan pendapat beberapa ulama yang berpedoman pada hadist Nabi yang diriwayatkan oleh Bukhori dari Ibn Abbas "Rasulullah berkata : perempuan janda berhak etrhadap dirinya daripadawalinya, sedangkan anak gadis diminta izinnya mengenai dirinya dan iziznnya adalah diamnya. Dalam suatu riwayat Abu Dawud dan Nasa'i tidak ada urusan bagiwali terhadap janda; dan gadis tidak mempunyai bapak (yatimah) diminta perintahnya."

Pernikahan seorang perempuan yang bekerja diluar negeri dengan sesama pekerja yang berada di perantauan. Dalam hal ini jika sang wali nasab mengetahui pernikahan tersebut dan menyetujui pernikahan tersebut (meskipun jauh) maka pernikahan nya tetaplah sah, namun jika sangwali nasab mengetahui pernikahan dan tidak menyetujuinya maka pernikahannya dianggap tidaklah, dan jika sang wali nasab tidak mengetahuinya maka pernikahan tetaplah tidak sah. Hal ini sesuai dengan penjelasan diatas, bahwa seorangwanita tidaklah sah menikah tanpa adanya wali, tanpa seizin wali, dan tidaklah sah pernikahan seorang wanita yang menikahkan dirinya.

Pernikahan seorang perempuan dengan seorang lelaki yang wali qaribnya (dekat) berada di penjara. Dalam hal ini sang peminang tidak ingin menunggu lama, karena takut untuk terjerumus ke hal hal yang tidak diinginkan (perzinahan) atau ketika menunggu lama akan terjadi kemudhorotan, ketika sang wali dipernjara tidak memungkinkan untuk datang, maka hak perwalian berpindah ke urutan beriutnya. Hal ini semata-mata hanya untuk menjaga kemaslahatannya. Pernikahan perempuan dengan seorang laki-laki ketika sang perempuan kesasar 
namun walinya masih ada. Ketika masih memungkinkan untuk komunikasi dengan sang wali, hendaknya wanita tersebut melakukan tawkil bil kitabah (mewakilkan perwalian melalui surat yang diketahui kepala KUA tempat wali berada/ tinggal). Namun jika tidak memungkinkan untuk komunikasi dengan sang wali dan tidak memungkinkan untuk pulang ke tempat wali berada, maka bisa menggunakan wali hakim. Ketika pernikahan orangtuanya tidak sah Dalam hal ini yang akan menjadi pernikahan bagi anak gadis yang lahit dari hasil pernikahan yang tidak sah (pernikahan orang tua sigadis yang memenuhi syarat rukun nikah atau perzinahan) maka perwaliannya jatuh pada wali hakim.

wali seorang perempuan yang lahir dari hasil hamil diluar nikah, namun pernikahan dari ibu dan ayah biologisnya. Menurut golongan Syafi'iyah ketika anak tersebut masih berupa darah tidaklah boleh dicampuri, namun menurut golongan Hanafiah boleh dicampuri. Dalam kasus ini ketika pernikahan terjadi saat anak tersebut masih berupa darah, maka yang akan menjadi walinya adalah ayah biologis tersebut, meskipun dari hasil hamil diluar nikah. Namun ketika pernikahan orang tuanya terjadi ketika anak tersebut sudah berupa anak, maka yang akan menjadi walinya adalah hakim. Hal ini sesuai dengan ukuran talaq yakni 4 bulan sepuluh hari.

Wali nikah seorang perempuan yang berasal dari hamil diluar nikah, namun pernikahan ibu bukan dengan ayah biologisnya. Menurut golongan Syafi'iyah sang ibu harus menunggu kelahiran anak tersebut, sehingga yang akan menjadi wali dari anak tersebut adalah hakim. Namun menurut pendapat golongan Hanafiah dan Abu Daud Ath-Thohiri boleh berhubungan tanpa menunggu kelahiran anak tersbut, namun yang akan menjadi wali nikahnya tetap ayah biologisnya. Dalam kasus ini ketika pernikahan yang terjadi anak tersebut masih berupa darah maka ayah tersebut boleh menjadi walinya, meskipun anak tersebut bukan dari ayah biologisnya. Namun ketika anak tersebut telah berupa anak maka yang harus menggunakan hakim. Dalam kasus perwalian pernikahan anak yang hamil/lahir diluar pernikahan, di Indonesia menggunakan peraturan perundang-undangan yakni menggunakan wali hakim karena hal ini semata-mata untuk menjaga kemaslahatan keluarga tersebut.

wali pernikahan ketika ayah kandung dari seorang wanita adalah berbeda agama. Sesuai dengan penjelasan diatas salah satu syarat menjadi wali dalam pernikahan adalah sesama agama. Jadi dalam hal ini jika seorang gadis muslim dan wali nasabnya adalah non muslim maka yang akan menjadi wali wanita tersebut adalah hakim. Di Indonesia perkawinan berbeda agama tidaklah bisa dilangsungkan.hal ini sesuai dengan hukum agam Islam bahwa menikah dengan yang berbeda agama tidaklah sah, sehingga ketika ada seorang wanita yang ingin JAS: Volume 2 Nomor 2, 2020 
menikah namun berbeda agam maka memilih cara menikah dengan salah satu agamanya, namun ketika mempunyai anak, dan anak tersebut muslim, dan sang ayah tidak beragama Islam, maka sang ayah tidaklah bisa menadi wali dalam pernikahanya. wali pernikahan ketika seorang wanita hasil dari hamil diluarnikah dengan yang lain agama. Sesuai dengan penjelasan diatas, seorang wali dan yang diwalilkan haruslah seagama, maka dalam hal ini yang bisa menjadi wali adalah pejabat KUA yang ditunjuk. Orang yang lain agama tidaklah berhak untuk menjadi seorang wali meskipun anak tersebut adalah hasil dari perbuatan zina yang kemudian sang ibu dinikahinya masih berupa darah atau yang sudah berupa anak dalam kandungan.

ketika ada anak gadis yang masih dibawah umur ingin menikah, namun yang menjadi wali nikah adalah kakeknya, bukan ayah kandungnya, padahal ayah kandungnya masih ada dan kuasa atas perwaliannya. Menurut Sayyid Sabiq dalam bukunya fikih sunnah Sesuai dengan penjelasan diatas, urutan perwalian tidaklah boleh dilangkahi atau diacak, dalam kasus ini ketika ayahnya masih ada dan kuasa maka tidaklah sah pernikahan yang menggunakan wali selain ayahnya, namun ketika takut malah terjerumus kedalam perzinahan, ketika ayahnya tidak menyetujuinya maka hendaklah menggunakan wali urutan setelahnya. Dalam hal pernikahan anak dibawah umur ayah kandung dan kakeknya boleh menikahkannya meskipun tanpa persetujuan anak tersebut. Hal ini karena anak yang masih dibawah umur belumlah dapat menentukan pendapatnya.

Namun golongan Syafi'iyah menganjurkan agar ayah fan kakek tidak menikahkan anak gadisnya masih dibawah umur hingga anak tersebut mencapai dewasa dan anak tersebut bisa berendapat serta mengizinkannya, hal ini disebabkan agar sianak nantinya tidak terjatuh padalelaki yang tidak disukainya. Tetapi kebanyakan ulama yang lain berpendapat bahwa jika sang wali bukanlah ayah dan kakeknya tidaklah boleh menikahkan anak gadisnya yang masih dibawah umur. Namun jika hal ini terjadi maka pernikahnnya tidaklah sah. Namun Abu Hanifah, Auzai dan segolongan ulama salaf membolehkan menikahkan anak dibawah umur, dan pernikahannya tetaplah sah, namun ketika anak tersebut telah baligh (dewasa), anak tersebut berhak Khiyar (menolak atau menerima (Sabiq, 1990: 20). Namun di Indonesia untuk anak yang masih berada di bawah umur ketika mau menikah harus menyertakan surat keputusan dari pengadilan untuk mengetahui apakah sang anak tersebut dapat / boleh menikah atau tidak.

wali dari gadis yang dihasilkan dari nikah mut'ah (kawin kontrak) Dalam kasus ini meskipun itu nikahnya nikah muta'ah (kawin kontrak), ketika menghasilkan sang anak maka yang akan menjadi wali dari anak tersebut adalah

JAS: Volume 2 Nomor 2, 2020 
ayah biologisnya. Namun di Indonesia nikah mut'ah tidaklah diberlakukan, hal ini semata-mata untuk melindungi hak wanita dan demi kemaslahatan keluarga.

\section{Simpulan}

Dari penjelasan diatas, dalam pernikahan perwalian menjadi syarat sah dan rukun dari pernikahan sehingga dalam pernikahan wali harus hadir ditempat, atau yang mewakilinya. jelaslah untuk menjadi wali dalam pernikahan tidaklah sembarang orang, namun haruslah memenuhi syarat dan rukunnya. Wali pernikahan selalu dari pihak ayah, hal ini disebabkan oleh adanya nasab (pertalian kekeluargaan yang didasakan pada pernikahan yang sah). Dari penjelasan diatas seorang anak bernasab pada ayahnya, sehingga jika aada anak yang mau menikh maka yang menjadi walinya adalah orang-orang yang jelas sedarah dengan anak tersebut. Tidak adanya wali pernikahan dari pihak ibu atau dari pihak saudara perempuan seperti halnya kakek dari ibu, saudara laki-laki ibu dan seterusnya. Dalam pernikahan hendaklah mengurutkan wali dari yang paling dekat sebagaimana yang dijelaskan diatas. Tidaklah boleh dilangkahi. Semisal memakai wali yang jauh, sementara wali yang dekat masih ada dan tidak ada udzur. Wali yang paling akhir untuk menikahkan seorang wanita mslim ialah wali hakim, wali hakim barulah bisa digunakan ketika wali sahnya yang bisa menikahkan memang sudah tidak ada. Ayah angkat dan saudara angkat tidaklah bisa menikahkan anak gadisnya, hal ini disebabkan oleh ayah angkat dan saudara angkat dan atau keturunannya bukanlah orang-orang yang sedarah dengannya, dan tidak ada hubungan kekerabatan yang sedarah. Namun untuk kasus jika anak angkat tersebut tidak diketahui silsilahnya maka barulah pengadilan agama yang bisa memutuskan wali nikah anak tersebut adalah ayah angkat. Dan bila ayah angkat telah meninggal dunia, maka yang menjadi wali nikahnya adalah wali hakim yag telah diberi kuasa utnutk menikahnkannya. Begitu juga ayah tiri tidaklah bisa menjadi wali dalam pernikahan anak tirinya.

Wali dalam pernikahan setiap orang jelaslah berbeda disetiap kasus,tidak semua wali dalam pernikahan adalah ayah. Tidaklah pernikahan seorang wanita tanpa wali, baik wali nasab (wali biologis) maupun wali hakim. Peran wali dalam pernikahan sangatlah diperlukan/penting. Hendaklah para yang akan menikha ketika akan menikah, sedangkan wali yang paling dekat(ayah) tidak mengizinkan, henadaklah mencari wlai yang lainnya (menggunakan kakek, saudara laki-laki sekandung, paman dll sesuai dengan urutannya) Di Indonesia berlaku setiap anak yang lahir dari hasil perzinahan menggunakan wali hakim. Hukum pernikahan seseorang yang menikah tanpa adanya wali adalah tidak sah pernikahannya. Menurut sayyid Sabiq dalam bukunya JIKA ada wanita menikahkan dirinya dengan

JAS: Volume 2 Nomor 2, 2020 
izin walinya atau tanpa izin walinya maka pernikahanny tidaklah sah (batal). Tetapi menurut Abu Hanifah, keluarga bukan Ashobah boleh menjadi walinya dalam perkawinan. Wallahu a'lam bish showab.

\section{Daftar Rujukan}

Alhamdani, H.S.A. 1989. Risalah Nikah (Hukum Perkawinan Islam) cet ke 3. Jakarta : Pustaka Amani.

Anwar, Moch. 1991. Dasar-Dasar Hukum Islam dalam Menetapkan Keputusan di Pengadilan Agama. Bandung: CV. Diponegoro.

Diretorat Pembinaan Badan Peradilan agama. 1992. Kompilasi Hukum Islam di Indonesia.

Ibrahim Hosen. 2003. Fiqih Perbandingan dalam Masalah Pernikahan cet ke 1. Jakarta : Pustaka Firdaus.

Nasihih Ulwan, Abdullah. 1992. Pendidikan Anak Menurut Islam Pendidikan Seks. Bandung: Remaja Rosdakarya

Rasjidi, Lilis. 1977. Hukum Perkawinan dan Perceraian di Malaysia dan Indonesia. Bandung: Alumni

Sabiq, Sayyid. 1990. Fikih sunnah. Bandung : PT. Al Ma'arif. 